\title{
NEUROPSYCHOPHARMACOLOGY REVIEWS Sex differences in stress reactivity in arousal and attention
} systems

\author{
Debra A. Bangasser ${ }^{1}$, Samantha R. Eck ${ }^{1}$ and Evelyn Ordoñes Sanchez ${ }^{1}$
}

Women are more likely than men to suffer from psychiatric disorders with hyperarousal symptoms, including posttraumatic stress disorder (PTSD) and major depression. In contrast, women are less likely than men to be diagnosed with schizophrenia and attention deficit hyperactivity disorder (ADHD), which share attentional impairments as a feature. Stressful events exacerbate symptoms of the aforementioned disorders. Thus, researchers are examining whether sex differences in stress responses bias women and men towards different psychopathology. Here we review the preclinical literature suggesting that, compared to males, females are more vulnerable to stress-induced hyperarousal, while they are more resilient to stress-induced attention deficits. Specifically described are sex differences in receptors for the stress neuropeptide, corticotropin-releasing factor (CRF), that render the locus coeruleus arousal system of females more vulnerable to stress and less adaptable to CRF hypersecretion, a condition found in patients with PTSD and depression. Studies on the protective effects of ovarian hormones against CRF-induced deficits in sustained attention are also detailed. Importantly, we highlight how comparing males and females in preclinical studies can lead to the development of novel therapeutics to improve treatments for psychiatric disorders in both women and men.

Neuropsychopharmacology (2019) 44:129-139; https://doi.org/10.1038/s41386-018-0137-2

\section{INTRODUCTION}

There are sex differences in the prevalence and presentation of many psychiatric disorders. For example, although men report more traumatic experiences than women, the rate of posttraumatic stress disorder (PTSD) diagnosis is still twice as high in women as in men $[1,2]$. Similarly, women are more frequently diagnosed with major depression than men [3, 4]. Another shared feature of PTSD and depression is hyperarousal, which is a defining cluster of symptoms in PTSD and contributes to certain features of depression (e.g., agitation, restlessness, sleep disruptions, ruminations, etc.) [5]. Compared to men, women with PTSD and depression have more hyperarousal symptoms, such as disrupted sleep, concentration difficulties, and increased ruminations [6-15]. These findings highlight hyperarousal as a key difference in the presentation of these disorders between the sexes.

Women are not always the more vulnerable sex when it comes to psychiatric disorders. Women are less frequently diagnosed than men with attention deficit hyperactivity disorder (ADHD) and schizophrenia, and women that suffer from schizophrenia typically develop it 3-5 years later in life than men $[16,17]$. Patients with ADHD and schizophrenia suffer cognitive deficits, and there are sex differences in the presentation of these deficits. For example, attention deficits and hyperactivity are greater in males than in females with ADHD [18-21]. In schizophrenia, cognitive deficits are reported in both sexes, but their presentation is often different [22]. With the exception of visual working memory, studies typically find that male schizophrenia patients have greater cognitive deficits than females $[22,23]$. There are several reports of greater attention impairments in males relative to females with schizophrenia [24-27], although other studies fail to find this sex difference $[16,28-30]$. These inconsistencies are likely attributable to sex-specific changes in attention that occur over time, because a longer duration of illness is associated with reduced attention in men $[22,30]$. When considering the clinical data together, it is apparent that despite the differences in symptoms that distinguish psychiatric disorders, there are some commonalities between psychiatric disorders with a sex bias. Namely, women are more likely to suffer from psychiatric disorders with hyperarousal as a symptom, while men are more likely to suffer from disorders with attention deficits.

One environmental factor that is associated with the onset and severity of a variety of psychiatric disorders is stress [31]. Exposure to a traumatic event is the precipitating factor for PTSD [5]. Additionally, chronic stress is associated with the onset of depression and schizophrenia and can exacerbate the symptoms of these disorders, as well as symptoms of ADHD [32-35]. The association between stress and disorders that are sex-biased implicates sex differences in stress responses as a factor that can drive distinct types of psychopathology in men and women. This review will detail preclinical data that demonstrate how stress can regulate the locus coeruleus (LC)-norepinephrine (NE) arousal system to shift females more easily than males into a state of hyperarousal. We will also describe how ovarian hormones promote female resilience to stress-induced attentional disruptions mediated by the basal forebrain cholinergic system. Importantly, a better understanding of sex-specific mechanisms for responding to stress can ultimately guide the development of better treatments for psychiatric disorders in men and women.

Sex differences in the LC-NE system

The pontine LC nucleus regulates arousal via its efferent projection system that releases NE throughout the neuroaxis [36-39]. In fact,

${ }^{1}$ Department of Psychology and Neuroscience Program, Temple University, Philadelphia, PA 19122, USA

Correspondence: Debra A. Bangasser (debra.bangasser@temple.edu)

Received: 27 February 2018 Revised: 21 May 2018 Accepted: 15 June 2018

Published online: 29 June 2018 


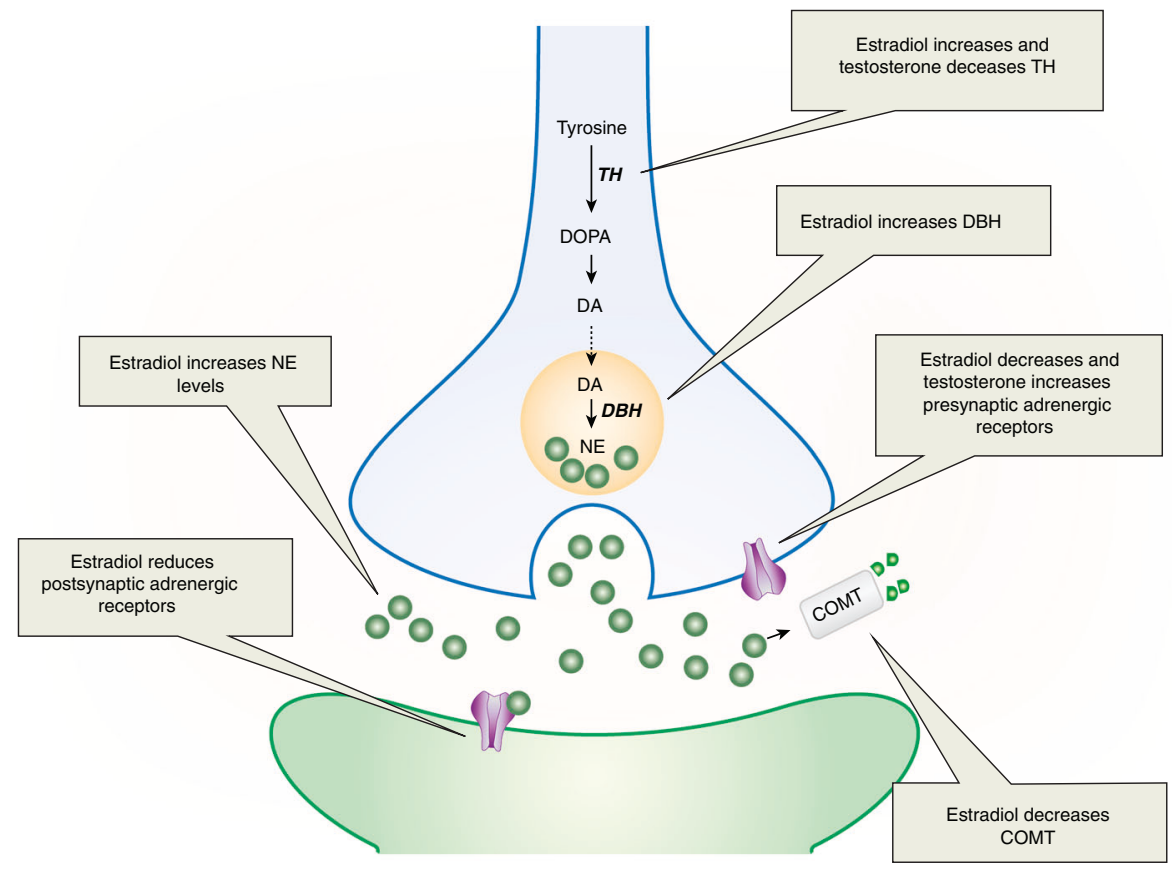

Fig. 1 This schematic shows how estradiol and testosterone regulate the LC-NE system. Estradiol enhances NE activity by increasing NE production in LC neurons (blue), decreasing COMT-dependent NE degradation, and reducing presynaptic adrenergic receptors that inhibit NE release. As a possible compensatory action, estradiol also reduces adrenergic receptors on postsynaptic neurons (green). In contrast, testosterone reduces $\mathrm{TH}$, the NE synthetic enzyme, while increasing presynaptic adrenergic receptors that inhibit NE release. DA dopamine, DBH dopamine $\beta$-hydroxylase, DOPA L-dihydroxyphenylalanine, COMT catechol-O-methyltransferase, NE norepinephrine

the LC is the sole source of NE for the cortex and hippocampus, regions critically involved in cognition and stress responsivity [3941]. NE release is correlated with arousal and driven by the firing of LC neurons [39, 42]. These neurons discharge in a tonic mode and the rate of tonic firing is positively correlated with electroencephalographic (EEG) activity and behavioral indices of arousal [43-45]. Additionally, sensory stimuli evoke phasic responses, or bursts of synchronous firing, from LC neurons [46, 47]. There are no sex differences in the tonic or phasic firing of LC neurons under unstressed conditions [48-50]. However, the LC of humans and certain rat strains is comprised of more neurons in females than males [51-56]. Thus, despite the similar electrophysiological properties of LC neurons in both sexes, the sex difference in LC size suggests that the female LC has a greater capacity to synthesize and release NE in target regions to increase arousal.

The LC is a target of estrogenic regulation, as it contains estrogen receptors (ERs) [57, 58]. Moreover, estradiol has been shown to regulate aspects of NE synthesis and degradation (Fig. 1, for review see[59]). Specifically, estradiol treatment of ovariectomized female rats increases tyrosine hydroxylase $(\mathrm{TH})$, the ratelimiting enzyme of catecholamine synthesis, as well as dopamine $\beta$-hydroxylase $(\mathrm{DBH})$, which catalyzes the formation of NE from dopamine $[60,61]$. These effects occur through direct regulation of the th and $d b h$ genes via estrogen response elements (ERE) on their promoters [61-63]. Estradiol can also reduce the breakdown of NE via its regulation of catechol-O-methyltransferase (COMT), an enzyme that degrades catecholamines. Estrogens decrease COMT activity in cell culture and COMT levels are lowest in the proestrous phase of the cycle, when estrogens are highest $[64,65]$. The estrogenic regulation of COMT may explain why COMT activity is lower in the prefrontal cortex of women compared to men [66]. Collectively, these findings reveal that estradiol increases NE synthetic enzymes, while decreasing degradative enzymes, effects that can account for the finding that estradiol treatment increases NE in target regions $[60,67]$.
The increase in NE by estradiol could suggest that activation of the NE system increases arousal more in adult females than males. Additionally, estradiol reduces $a_{2}$-adrenergic receptors in the cortex [68], which are presynaptic in this region and serve to inhibit NE release [69]. This estradiol-induced receptor alteration could further promote cortical NE release in females. However, conditions of high estradiol have also been associated with a reduction in postsynaptic $\beta 1$-adrenergic receptors in the cortex and striatum [70, 71], but see [72]. These reductions in postsynaptic adrenergic receptors due to estradiol may be compensatory for the estradiol-induced increase in $\mathrm{NE}$, making the net effect of NE similar for males and females. The fluctuation of estradiol during a female's reproductive years suggests frequent, cyclical changes in NE levels, and adrenergic receptor expression. This dynamic regulation may be more prone to error than a system that maintains NE and adrenergic receptor levels in a stable state. A failure of estradiol to decrease postsynaptic adrenergic receptor expression, for example, could lead to too much NE tone, increasing arousal. More data are needed, however, to determine whether circuits modulated by cyclical hormones are more prone to dysregulation than those not influenced by cyclical hormones. Additionally, although data do indicate that estradiol alters $a_{2}$-adrenergic receptors in cortex but not hypothalamus [68], much more research is needed to determine whether estradiol regulation of adrenergic receptors is restricted to brain regions involved in arousal and cognition, or more widespread.

Unlike studies on estrogens, the role of testosterone in regulating $\mathrm{NE}$ synthesis and release has not been extensively investigated. However, there is evidence that gonadectomizing male rats increases $\mathrm{TH}$ in the LC [73]. This result suggests that testosterone normally suppresses $\mathrm{TH}$, which would thereby reduce NE synthesis. This suppression could happen via direct regulation of LC by testosterone, because androgen receptors are present in the LC [74]. There is some evidence to suggest testosterone alters presynaptic adrenergic receptors. Specifically, testosterone 


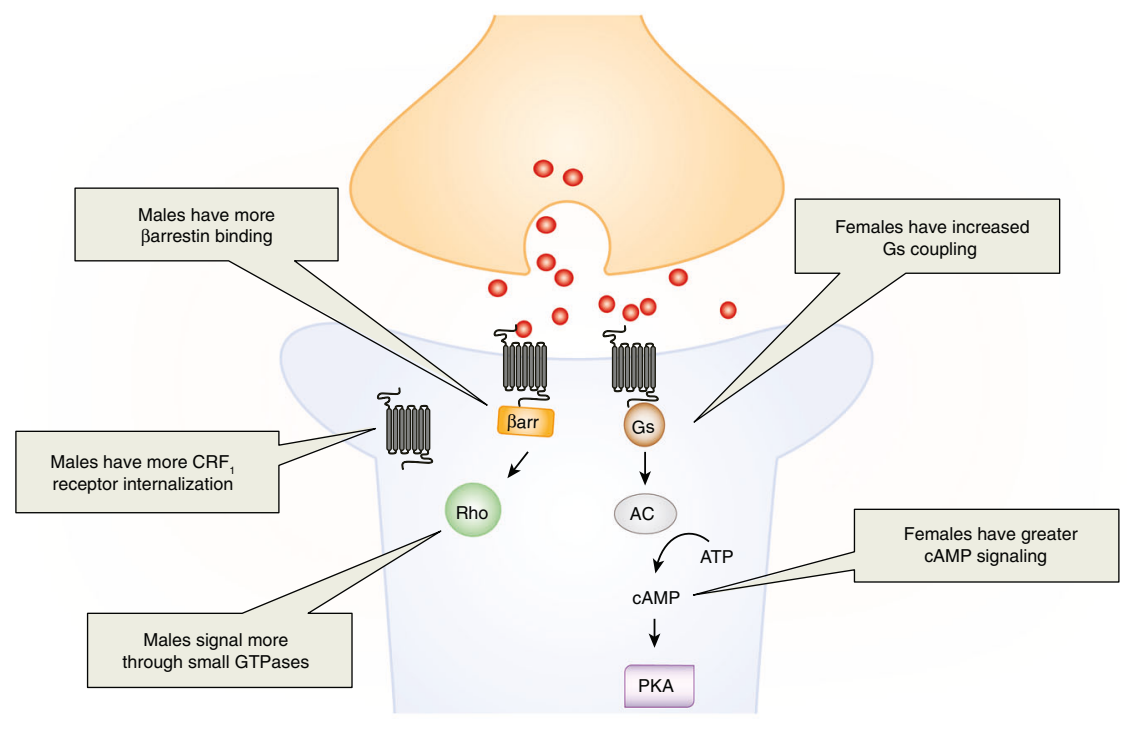

Fig. 2 Sex differences in $\mathrm{CRF}_{1}$ receptor signaling and trafficking in LC neurons (blue). In males, CRF 1 receptors bind $\beta$ arrestin2 and signal through small GTPases signaling pathways, such as Rho. This $\beta$ arrestin2 binding is associated with $\mathrm{CRF}_{1}$ receptor internalization in males. In females, $\mathrm{CRF}_{1}$ receptors couple to the Gs protein to initiate CAMP-PKA signaling and their receptors do not internalize following stress or CRF hypersecretion.

treatment of castrated male rats up-regulates $a_{2}$-adrenergic receptor mRNA in cortex, an effect that would reduce NE release [75]. Collectively, the limited data on testosterone's regulation of the LC-NE system suggest that, opposite to estradiol's effects, testosterone reduces NE synthesis and release. Given that males have higher testosterone levels than females, this effect could translate into lower levels of NE in males compared to females.

In addition to factors that can differentially affect LC output in males vs. females, there are structural sex differences in LC dendrites that can affect the processing of LC inputs [49, 76]. LC afferents are topographically organized, such that inputs carrying mainly autonomic information from the brainstem synapse on dendrites in the LC core, which is the main cluster of NEcontaining cell bodies $[77,78]$. Yet LC dendrites are not restricted to the core, but also extend into the dorsolateral and ventromedial pericoerulear (peri-LC) regions [79, 80]. Inputs from the paraventricular nucleus of the hypothalamus (PVN) synapse on dendrites in the core, as well as dorsolateral peri-LC [81]. Structures that are part of the extended amygdala, including the central nucleus of the amygdala (CeA) and bed nucleus of the stria terminalis (BNST), carry emotion-related information to the dorsolateral peri-LC [8184]. The ventromedial peri-LC receives inputs from the nucleus of the solitary tract and periaqueductal gray [81, 84, 85]. This topographic organization of inputs is important to consider in the context of sex differences in dendritic morphology. Female rats and mice have longer and more complex LC dendrites than males $[49,76]$. The shorter dendrites in males would be expected to adequately receive inputs to the LC core, but they may not contact as many inputs in the peri-LC as the longer dendrites of females, which expand further into this region. Consistent with this circuitry, immunoreactivity for the synaptic vesicle protein, synaptophysin, is denser in the dorsolateral peri-LC region in female relative to male rats [76]. This result suggests that, compared to the male LC, the female LC integrates more information from extended amygdala and hypothalamic inputs. Given that these inputs are critical for processing both positive and negative salient stimuli, this morphological sex difference in LC dendrites could increase female arousal in response to emotional events. During a stressor, this sex difference could translate into greater arousal to the aversive stimulus. Consistent with this idea, a human imaging study found that woman with irritable bowel syndrome have greater activation of an amygdalaLC circuit in response to an aversive visceral stimulus than men with this disorder [86]. More studies are needed to determine whether similar sex differences in amygdala-LC connectivity are found in response to other types of aversive stimuli in humans.

Sex differences in stress regulation of the LC

Stressor exposure can increase arousal. The mechanism by which this effect occurs involves the regulation of the LC-NE system by the stress neuropeptide, corticotropin releasing factor (CRF) [8790]. During a stressful event, CRF is released into the LC, which causes $L C$ neurons to change their firing to a high tonic-low phasic mode $[87,89,91,92]$. This mode of firing increases cortical EEG and can shift behavior such that an animal changes from focusing on a stimulus to scanning the environment $[93,94]$. Scanning the environment for potential threats is typically an adaptive response to stress. However, if this shift occurs inappropriately or persistently it can cause irrelevant stimuli in the environment to elicit responses, resulting in a state of hyperarousal.

There are sex differences in CRF regulation of LC-NE physiology $[48,50]$. When CRF is applied locally into the LC, certain doses of CRF that fail to activate LC neurons of male rats increase the firing rate of $L C$ neurons in female rats. In fact, the CRF-dose-response curve for LC activation is shifted to the left in females compared to males, indicating that female LC neurons are more sensitive to CRF. As noted, CRF mediates stress effects on the LC, therefore it is not surprising that female LC neurons are also more sensitive to activation by hypotensive stress than male LC neurons [50]. This electrophysiological sex difference would lead to greater arousal in response to stress in females than males. Surprisingly, gonadal hormones do not regulate the physiological sex difference in LC sensitivity [48, 50]. Therefore, this sex difference must be established either by hormonal surges earlier in development or by the different complement of genes on the sex chromosomes [95].

The sex difference in LC firing to local CRF administration indicates that there is something different about male and female postsynaptic responses to $C R F$, which are mediated by $\mathrm{CRF}_{1}$ receptors in the $\mathrm{LC}[96,97]$. The $\mathrm{CRF}_{1}$ receptor is promiscuous and can couple to multiple signaling proteins, but it typically binds $\mathrm{Gs}$ to activate the CAMP-PKA signaling cascade [98-100]. In the LC, 
132

activation of CAMP-PKA signaling mediates the increase in neuronal firing following CRF administration [97]. Thus, increased activation of this pathway in females, compared to males, could explain their greater LC response to CRF. One way that females could increase CAMP-PKA signaling would be through increased coupling of $\mathrm{CRF}_{1}$ receptors to $\mathrm{Gs}$. Indeed, we found greater $\mathrm{CRF}_{1}-\mathrm{Gs}$ coupling in female than male rats (Fig. 2) [48]. Consistent with this result, the CRF-induced increase in LC firing in females is completely CAMP-PKA mediated, highlighting the prominence of this pathway [50]. In contrast, this pathway only partially mediates the CRF-induced increase in LC firing in males. This result suggests that, not only are there sex differences in the amount of CAMPPKA signaling, but there are sex differences in the types of signaling cascades activated by the $\mathrm{CRF}_{1}$ receptor.

We further tested the idea that the $\mathrm{CRF}_{1}$ receptor signals through different pathways in males and females using CRF overexpressing (CRF-OE) mice, which were designed to model the CRF hypersecretion that occurs in patients with PTSD and depression [101-103]. The high levels of CRF in these mice lead to CRF receptor activation, which we assessed with phosphoproteomic analysis of cortical tissue, which contains the $\mathrm{CRF}_{1}$ receptor subtype and sufficient material for proteomics [104, 105]. This approach allowed us to assess sex differences in activated signaling pathways by determining differences in their phosphorylation following CRF hypersecretion. Not surprisingly, the proteins in the CAMP-PKA signaling pathways were enriched for phosphopeptides in female CRF-OE mice. This result suggests greater activation of this pathway in females, a finding which is consistent between the LC and cortex. In males, however, CRF hypersecretion enriched phosphopeptides in small GTPases signaling pathways, including Rho (Fig. 2). Activation of Rho is not downstream of $\mathrm{Gs}$, suggesting that other proteins must drive this signal transduction in males. One signaling molecule that can activate small GTPases is ßarrestin2 [106, 107]. Interestingly, Barrestin2 binds to the $\mathrm{CRF}_{1}$ receptor at low levels in both sexes in the unstressed state, but stress increases the association of the $\mathrm{CRF}_{1}$ receptor with $\beta$ arrestin2 only in male rats [48]. Thus, when considered together these studies reveal that the $\mathrm{CRF}_{1}$ receptor signals more through the Gs-CAMP-PKA-mediated pathways in females and more through ßarrestin2-small GTPase-mediated pathways in males $[108,109]$. The data from the cortex and LC reveal a similar pattern of sex-biased $\mathrm{CRF}_{1}$ receptor signaling in both regions, but it remains to be determined whether these sex differences occur consistently throughout the brain or whether they are region specific.

Cellular signaling pathways can have distinct functions. Thus, sex differences in $\mathrm{CRF}_{1}$ receptor signaling can bias males and females towards different physiological responses, some of which may translate into differences in disease risk. As an example, phosphorylated proteins in female CRF-OE mice are overrepresented in Alzheimer's disease (AD)-related pathways involved in tau phosphorylation and amyloid processing [104]. In a mouse model of $A D$ pathology in which the mice express the human $\beta$ site amyloid precursor, CRF overexpression increases the phosphorylation of $\beta$-secretase more in females than males [104]. $\beta$ secretase is the enzyme involved in the formation of amyloid $\beta$ and CRF hypersecretion in this mouse model resulted in more amyloid $\beta$ plaque formation in females compared to males. These studies highlight how activation of $\mathrm{CRF}_{1}$ receptors can lead to different pathological consequences in males and females. Yet it is likely that these effects are not limited to $\mathrm{CRF}_{1}$ receptors because these receptors share similarities to many other G-protein-coupled receptors (GPCRs) [110, 111]. Therefore, sex differences in intracellular signaling may be an important, though underexplored, mechanism that contributes to sex differences in pathology.

In addition to signaling differently, $\mathrm{CRF}_{1}$ receptors are also trafficked differently in LC dendrites of male and female rodents
(Fig. $2[48,49])$. Like most GPCRs, $\mathrm{CRF}_{1}$ receptors internalize, or move from the plasma membrane into the cytosol in response to saturating concentrations of CRF [110, 112]. Once internalized, these receptors can no longer be activated, which can be a compensatory response that protects neurons from overactivation in the presence of elevated levels of CRF release. $\mathrm{CRF}_{1}$ receptor internalization is initiated when $\beta$ arrestin2 binds to the receptor, moving it into clathrin-coated pits for endocytosis [113, 114]. As noted, stress increases $\beta$ arrestin2-CRF ${ }_{1}$ receptor binding in male, but not female rats [48]. Consistent with this finding, $\mathrm{CRF}_{1}$ receptor internalization was observed following stressor exposure in the LC of male rats, an effect that was not observed in females $[48,115]$. A lack of $\mathrm{CRF}_{1}$ receptor internalization in females may decrease their ability to adapt to conditions of CRF hypersecretion. Indeed, there is evidence that LC neurons of male CRF-OE mice adapt to excessive CRF release, such that their LC neurons fire at wild type levels, despite high levels of CRF in their LC [49]. In contrast, LC neurons of female CRF-OE mice do not adapt to excess CRF and fire three times faster than wildtype mice. This effect is linked to sex differences in $\mathrm{CRF}_{1}$ receptor internalization [49]. Paralleling the findings in stressed rats [48], $\mathrm{CRF}_{1}$ receptors internalize in male, but not female CRF-OE mice [49]. These studies identified a mechanism underlying female vulnerability to conditions of CRF hypersecretion and suggest that females may experience more hyperarousal symptoms than males under conditions of excessive CRF release.

Taken together, these studies reveal that the female LC is more sensitive to stress and less adaptable to conditions of CRF hypersecretion than the male LC. Moreover, recent work has found that recovery from stress-induced LC activation, which is mediated by $\mu$-opioid receptors (MORs), is not as efficient in females as in males, because females have lower levels of MORs [116]. When considered along with the sex differences in LC sensitivity to CRF, these findings reveal how the female LC-NE arousal system has a greater and more persistent response to stress than the arousal system of males. Perhaps in certain circumstances this heightened arousal would be adaptive for females, allowing them to better survey their environment for threats. However, in response to protracted stress, a traumatic event, or conditions of CRF hypersecretion, these sex differences would make females more easily shift into the dysregulated state of hyperarousal. If similar sex differences are found in the human brain, they may help explain female vulnerability to disorders with hyperarousal and CRF hypersecretion as a key feature, including depression and PTSD $[1,3,5,101,103]$.

\section{Sex differences in other arousal systems}

Arousal is not only mediated by the LC-NE system. Other brainstem monoaminergic neurons (serotonergic, dopaminergic) are involved, along with brainstem cholinergic centers $[117,118]$. In addition, arousal is regulated by hypothalamic histaminergic and orexigenic neurons, as well as brainstem and hypothalamic GABA and glutamate [117]. Some sex differences in these circuits have been reported. In the case of histamine, for example, there is greater histamine receptor binding in female than male rats, an effect that is linked to estradiol $[119,120]$. Yet how stress regulates histamine to alter arousal and any sex differences therein is unknown. In contrast, there are data on sex differences in stress regulation of serotonergic and dopaminergic systems; however, these data do not focus on arousal, but rather domains, such as depressive-like behavior and decision making (e.g. [121-124]). Thus, unlike in the LC, how sex and stress interact to modulate these other systems to regulate arousal has not been thoroughly explored. Clearly more studies are warranted.

Recent work by Grafe and colleagues [125] on sex differences, stress, and orexins is starting to address this gap. There are baseline sex differences in the orexin system such that female rats express more of the precursor, prepro-orexin, in the hypothalamus 


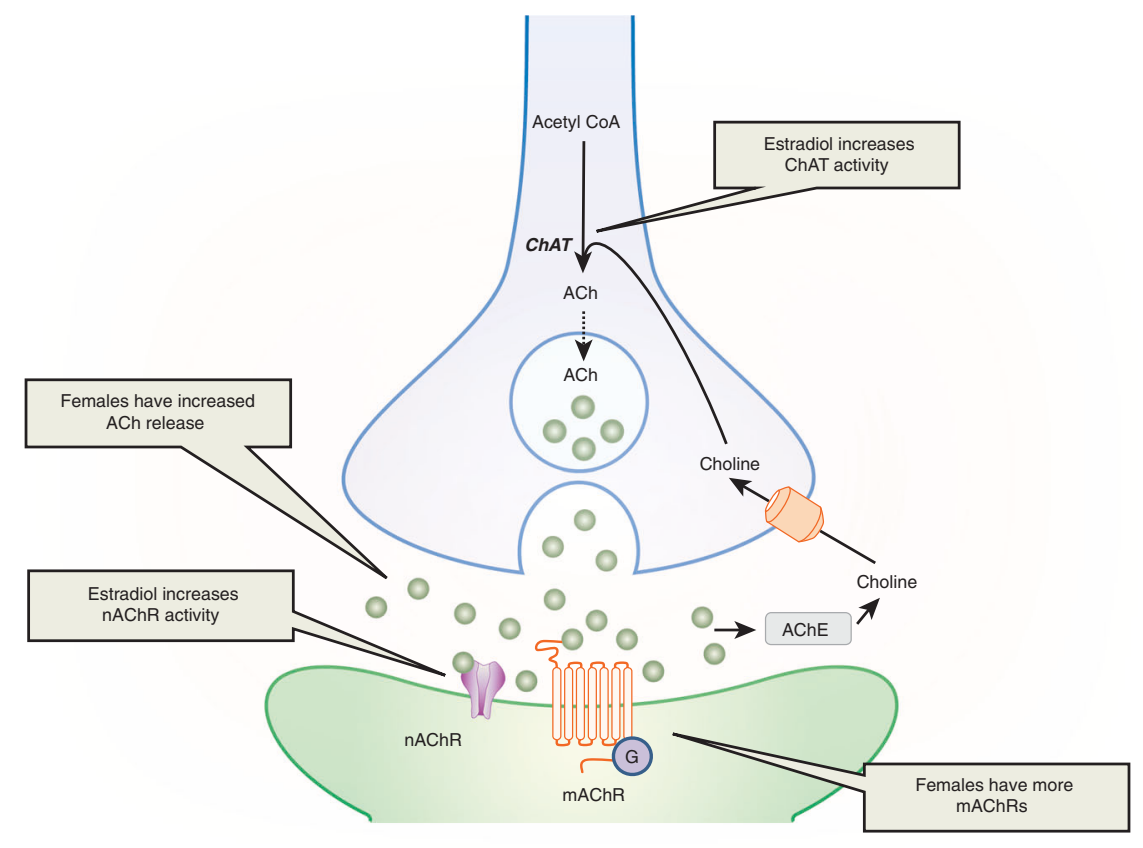

Fig. 3 This image illustrates sex differences in ACh activity and its regulation by estradiol. Females have enhanced ACh production in cholinergic neurons (blue) and greater ACh release. At the postsynaptic level, females have greater levels of nAChRs and mAChRs. ACh acetylcholine, AChE acetylcholinesterase, ChAT choline acetyl transferase, mAChR muscarinic acetylcholine receptor, nAChR nicotinic acetylcholine receptor

and have more orexin- $A$ in their cerebrospinal fluid than male rats $[125,126]$. This sex difference can be further driven by stress because the glucocorticoid receptor (GR) is enriched at the orexin promoter of females relative to males [125]. This increased orexin in females impacts their ability to adapt to repeated stress. Unlike male rats, which habituate to repeated restraint stress, female rats do not habituate to this repeated stressor exposure unless their hypothalamic orexin neurons are inhibited [125]. This result suggests that the elevated levels of orexins in females increase their arousal, making them less able to adapt to multiple exposures to the same stressor. One consequence of this sex difference is that female rats have impaired cognitive flexibility relative to male rats following repeated stress [125]. Inhibiting hypothalamic orexin neurons in females prevents this deficit. If a similar sex difference in orexin is found in humans, it could help explain sex differences in disorders like major depression and anorexia nervosa, where stress and deficits in cognitive flexibility are risk factors [127-129].

Sex differences in the cholinergic-attention system The basal forebrain is critical for cognition [130]. Although the basal forebrain contains many types of neurons (e.g., GABAergic, glutamatergic), it is characterized by the presence of cholinergic neurons [131]. Cholinergic neurons in the medial septum (MS) and the vertical limb of the diagonal band project to the hippocampus to modulate mnemonic processes [132-134]. Cortically mediated attentional processes are regulated by acetylcholine (ACh) [135137], and the sources of ACh for the cortex are the cholinergic neurons in the nucleus basalis of Meynert (NBM), substantia innominata, and the horizontal limb of the diagonal band of the basal forebrain [131]. Detailed studies have investigated the role of this cholinergic, basal forebrain corticopetal system in regulating sustained attention, the ability to detect intermittent and unpredictable events [138-140]. Cholinergic neurons in the NBM mediate the phasic release of cholinergic transients in the medial prefrontal cortex (mPFC), which allows for the detection of signaled events from non-signaled events in a sustained attention task (SAT) [141-143]. Given the basal forebrain's ability to regulate memory and attention, it is not surprising that drugs targeting the cholinergic system are used to treat cognitive deficits in AD [144146] and their therapeutic potential is also being assessed for improving cognition in patients with schizophrenia and ADHD [147, 148].

There are sex differences in the basal forebrain cholinergic attention system. While there is a circadian release of ACh in both males and females, females have greater overall $A C h$ release than males in cortical areas, including the mPFC (Fig. 3) [149, 150]. This increased release in females may result from an increased capacity of the NBM neurons to produce ACh. There is some evidence that, compared to the male NBM, the female NBM contains more neurons positive for choline acetyltransferase (ChAT), the cholinergic synthetic enzyme [149, 150], but see [151]. This sex difference in ChAT positive neurons could mean that females have more cholinergic neurons in this region and/or that females produce more ChAT than males, making it easier to count ChAT-positive neurons. Sex differences in ChAT production are possible because ovarian hormones regulate ChAT. In primates, ovariectomy reduces ChAT fibers in the PFC, which originate from the NBM [152]. In rats, replacement of ovariectomized females with estradiol increases ChAT-positive neurons in the NBM, as well as ChAT activity in the PFC [153-155]. Estrogens are poised to directly regulate NBM cholinergic neurons because these neurons contain estrogen receptor alpha $(\mathrm{ERa})$ and the $\mathrm{G}$-protein coupled estrogen receptor, GPR30 [151, 156, 157]. Estrogens are thought to provide tropic support to cholinergic neurons via modulation of neurotrophin receptors, including TrkA and TrkB, in the NBM $[158,159]$. In contrast to the regulatory effects of estrogens on the basal forebrain cholinergic attention system, the limited data on testosterone reveals that it does not regulate ChAT in the NBM [160]. Collectively, these finding suggest that females have a greater capacity than males to produce and release $\mathrm{ACh}$ into cortical regions crucial for attention and that this 
134

sex difference is linked to estradiol regulation of cholinergic neurons.

ACh exerts its effects through nicotinic ACh receptors ( $n A C h R s)$ and muscarinic $A C h$ receptors (mAChRs), and there are sex differences in their distribution (Fig. 3). In humans, healthy women have more $n A C h R s$ containing the $\beta 2$ subunit in their frontal cortex than healthy men [161]. The $\beta 2$ subunit most commonly pairs with the a4 subunit to form a $4 \beta 2$ nAChRs in the frontal cortex [162]. While rat a $4 \beta 2$ nAChRs lack an estrogen-binding site, in humans, estradiol directly potentiates $A C h$-evoked responses by binding to a site at the C-terminal tail of the a4 subunit of nAChRs $[163,164]$. Declining estrogen levels in postmenopausal females, therefore, may be linked to lower ACh action [165]. Because cognitive deficits in $A D$ have been linked to declining $n A C h R s$ in the cortex [166], this finding may help explain why older women are more susceptible to developing $A D$ symptoms than men, though studies examining this possibility have reported conflicting results [167].

Similar sex differences are seen in muscarinic ACh receptors ( $m A C h R s)$. Both human and rat studies have demonstrated that there are more mAChRs in the frontal cortex of females than males $[168,169]$. Like nAChRs, mAChRs are also subject to estrogenic regulation. Premenopausal women have greater $m A C h R$ density in the frontal cortex than postmenopausal women, and estrogen therapy increases mAChR density in the frontal cortex of postmenopausal women [170]. Taken together, these studies reveal that the female cortex not only receives more $A C h$ release than the male cortex, but it also has a greater capacity to respond to that signal due to higher levels of both nAChRs and mAChRs.

Sex differences in the cholinergic, basal forebrain corticopetal system could translate into sex differences in sustained attention. In both male and female rats, accurate detection of signals in the SAT task requires NBM cholinergic neurons [138]. Thus, both sexes rely on this cholinergic circuitry to sustain attention. Surprisingly though, sex differences are not observed in SAT performance [171, 172]. Perhaps there is a compensatory mechanism, which has yet to be identified, that helps males maintain attention despite having less cortical ACh and less capacity to respond to ACh. Alternatively, molecular sex differences in the cholinergic attention system may not be drastic enough to result in sex differences in behavior under normal conditions, but differences may emerge when the system is pushed, as it would be with stress and stress hormone exposure.

Our laboratory wanted to determine whether CRF disrupted sustained attention in male and female rats. To this end, we infused CRF throughout the brain and assessed performance on SAT. We found that CRF dose-dependently decreases performance on signal and non-signal trials in SAT and it has a similar effect in both sexes [172]. However, further analysis revealed an effect of estrous cycle phase in females [172]. CRF impairs SAT performance when females are in cycle stages with lower levels of ovarian hormones (i.e, diestrus I and II), but has no effect when females are in the cycle stages with higher levels of ovarian hormones (i.e., proestrus and estrus). These findings suggest that high circulating levels of ovarian hormones are protective against the negative effect of CRF on sustained attention. Males that never have elevated levels of ovarian hormones would not benefit from this protection.

It is notable that this modulatory effect of cycle stage was not observed in females when tested in the control condition (i.e., infused with the vehicle) [172]. Perhaps an increase in ChATactivity due to ovarian hormones does not have a measurable effect on SAT when females are unstressed and performing the task well, but does make a difference under conditions of CRF release that would otherwise impair performance. Another possibility is that ovarian hormones and the effects of CRF interact to impact attention. We performed functional connectivity analyses to assess circuits activated by central administration of
CRF (as measured by CFOS) and compared how sex and cycle stage altered these circuits $[173,174]$. Of relevance for SAT, functional connectivity between the NBM and MPFC in rats treated with CRF is different in proestrous females than in both diestrous females and males. This result suggests an interaction between ovarian hormones and CRF in the basal forebrain corticopetal system. How this interaction occurs remains unknown. Perhaps the downstream consequences of CRF receptor signaling are mitigated by the activation of estrogen receptor signaling, resulting in a neuroprotective effect. Another possibility is that CRF receptors and GPR30 interact physically to change signaling, which is possible because these receptors form heterodimers in other brain regions [175]. More work is needed to understand the mechanisms by which ovarian hormones modulate CRF-induced attention deficits.

There is emerging evidence that chronic stress also disrupts sustained attention. Over the course of the 6-day variable stressor exposure, SAT performance declines [176]. This effect is especially pronounced in male compared to female rats, and this sex difference is more apparent when attentional demands are high. How chronic stress alters attention circuitry and the cause of the sex difference therein are being explored. Given that CRF is released during chronic stress [177] and ovarian hormones protect against the negative effects of CRF on SAT, it is likely that circulating ovarian hormones similarly protect females against the effect of chronic stress on attention. Future studies are needed to test this idea.

Preclinical studies on stress impairments in attention are limited, and aside from the aforementioned studies, previous research has not considered females [178, 179]. However, the observed male vulnerability to stress-induced attention deficits is similar to prior work demonstrating male vulnerability to stressinduced mnemonic deficits. Specifically, spatial and recognition memory are impaired by chronic stress in male rodents [180-186]. In females, in contrast, chronic stress typically improves spatial memory without affecting recognition memory [182, 183, 185188 ]. The ability to sustain attention is critical for these mnemonic processes, so it is possible these sex differences in stress effects on memory are driven, at least in part, by sex differences in stress regulation of attention. Yet there are also sex-specific effects of chronic stress on regions directly involved in memory, such as the hippocampus [189, 190]. Dissociating stress effects on attention from stress effects on mnemonic processes, and sex differences therein, will be critical for developing more targeted interventions for improving cognition.

Collectively, these findings on stress and attention reveal sex differences in the basal forebrain attention system that emerge, at least in part, from ovarian hormone regulation of cholinergic neurons. When the system is pushed by chronic stress, sustained attention is more disrupted in males than females, and high circulating levels of ovarian hormones in females protect them from the negative effect of CRF on attention. Clinically, men are more likely than women to suffer from ADHD and schizophrenia, and symptoms of these disorders are exacerbated by stress [16, $17,34,35]$. Thus, sex differences in vulnerability of the basal forebrain attention system to stress may contribute to the higher rates of disorders with attention disruptions as a key feature in men compared to women.

\section{FUTURE RESEARCH DIRECTIONS}

The studies reviewed here reveal that arousal and attention systems are regulated by gonadal hormones and differentially affected by stress in males and females. Clinically, these sex differences could translate into differences in the efficacy of current medications that target these systems. However, clinical data on this topic is lacking because, although drug trials collect data by sex, few studies compare results between the sexes [191, 
192]. Take, for example, the case of acetylcholinesterase inhibitors (AChEl), which have been prescribed for Alzheimer's disease for decades, so knowledge of sex differences in drug effects would be anticipated [191]. However, two recent reviews found that there is almost a complete lack of sex-specific reporting on AChEl drug trial data [191, 193]. In fact, none of the trials assessing AChEI safety and tolerability in Alzheimer's patients reported findings of by sex [193]. Clearly, more efforts to compare drug trial effects by sex are needed to decrease harmful side-effects and reduce research value lost [194].

Preclinical data on stress regulation of arousal and attention circuits also remain sparse, particularly when it comes to understanding mechanisms that alter arousal and attention in females. This knowledge gap results from the exclusion of female subjects in basic neuroscience research $[195,196]$. The good news is that the traditional approach of only studying males is changing due to increased pressure from funding agencies, such as the National Institutes of Health in the United States, to consider sex as a biological variable in non-human animal studies [197]. From a basic research standpoint, this more inclusive approach will increase our knowledge of the female brain. An additional benefit is that the application of this basic knowledge will improve health outcomes, especially for women. Adverse drug reactions occur more often in women than in men [198-200]. While there are many potential reasons for this disparity, the omission of female subjects from preclinical studies that drive drug discovery certainly plays a role.

An important benefit of including both males and females in basic research studies is that comparing the sexes can reveal novel mechanisms that could be leveraged into new treatments. As an example, $\mathrm{CRF}_{1}$ receptor antagonists have been pursued for years as a potential therapy for PTSD and depression, given the clear role of the $\mathrm{CRF}_{1}$ receptor activation in contributing to these disorders [201, 202]. Unfortunately, these drugs have not met with much success clinically, perhaps because these compounds were developed in male animals but then tested for efficacy primarily in female patients $[123,203,204]$. Thus, new approaches are needed. By comparing the $\mathrm{CRF}_{1}$ receptors in males and females, a new idea for treatment emerges $[109,205]$. As noted, the $\mathrm{CRF}_{1}$ receptor signals more through $\beta$ arrestin-mediated pathways in males and more through Gs-mediated pathways in females, and this Gsinduced signaling heightens sensitivity of the LC arousal system in females [48, 104]. Biased ligands that shift signaling from Gsmediated pathways to ßarrestin-mediated pathways have been developed for other receptors [206-208]. The data presented here suggest that, if a ligand was developed for the $\mathrm{CRF}_{1}$ receptor that could shift the conformation of the receptor to better bind Barrestin in females, it could mitigate the hyperarousal symptoms in PTSD and depression, particularly in women. Importantly, this potential treatment strategy emerged only by comparing the sexes to identify factors that promote resilience vs. vulnerability to stress-induced arousal.

Most psychiatric disorders are sex-biased in their prevalence and/or presentation and have stress as a contributing factor [31, $209,210]$. Thus, the study of sex differences in stress responses is particularly relevant for neuropsychopharmacology. Although the focus of this review is on arousal and attention, sex differences in stress regulation of many domains (e.g., negative valence, social processing, etc.) should be considered to better understand the etiology of psychiatric disorders and improve their treatment. More broadly, as the field of neuropsychopharmacology moves towards developing personalized medicine, sex must be considered as factor. The influence of sex on the development and treatment of psychiatric disorders, however, can only fully be understood if both sexes are included and compared in the experimental design of basic studies that serve as the basis for the development of novel therapeutics.

\section{ACKNOWLEDGEMENTS}

This work was supported by an NSF CAREER grant IOS-1552416 and Pennsylvania Department of Health grant 420792 to DAB and T32 DA007237 to SRE.

\section{ADDITIONAL INFORMATION}

Competing interests: The authors declare no competing interests.

Publisher's note: Springer Nature remains neutral with regard to jurisdictional claims in published maps and institutional affiliations.

\section{REFERENCES}

1. Breslau N. The epidemiology of trauma, PTSD, and other posttrauma disorders. Trauma Violence Abuse. 2009;10:198-210.

2. Luxton DD, Skopp NA, Maguen S. Gender differences in depression and PTSD symptoms following combat exposure. Depress Anxiety (1091-4269). 2010;27:1027-33.

3. Kessler RC, Petukhova M, Sampson NA, Zaslavsky AM, Wittchen HU. Twelvemonth and lifetime prevalence and lifetime morbid risk of anxiety and mood disorders in the United States. Int J Methods Psychiatr Res. 2012;21:169-84.

4. Tolin, Foa. Sex differences in trauma and posttraumatic stress disorder: a quantitative review of 25 years of research. Psychl Bull. 2006;132:959-92.

5. American Psychiatric Association. Diagnostic and statistical manual of mental disorders: DSM-5. 5th ed, Vol. 5 Washington, DC: American Psychiatric Publishing; 2013.

6. Nolen-Hoeksema S, Larson J, Grayson C. Explaining the gender difference in depressive symptoms. J Pers Soc Psychol. 1999;77:1061-72.

7. Peters L, Issakidis C, Slade TIM, Andrews G. Gender differences in the prevalence of DSM-IV and ICD-10 PTSD. Psychol Med. 2005;36:81-89.

8. Plante DT, Goldstein MR, Landsness EC, Peterson MJ, Riedner BA, Ferrarelli F, et al. Topographic and sex-related differences in sleep spindles in major depressive disorder: a high-density EEG investigation. J Affect Disord. 2013;146:120-5.

9. Plante DT, Landsness EC, Peterson MJ, Goldstein MR, Riedner BA, Wanger T, et al. Sex-related differences in sleep slow wave activity in major depressive disorder: a high-density EEG investigation. BMC Psychiatry. 2012;12:146.

10. Thomsen DK, Yung Mehlsen M, Christensen S, Zachariae R. Rumination-relationship with negative mood and sleep quality. Pers Individ Differ. 2003:34:1293-301.

11. Frank $E$, Carpenter L, Kupfer D. Sex differences in recurrent depression: are there any that are significant? Am J Psychiatry. 1988;145:41-5.

12. King $M W$, Street $A E$, Gradus JL, Vogt DS, Resick PA. Gender differences in posttraumatic stress symptoms among OEF/OIF veterans: an item response theory analysis. J Trauma Stress. 2013;26:175-83.

13. Kobayashi I, Mellman TA. Gender differences in sleep during the aftermath of trauma and the development of posttraumatic stress disorder. Behav Sleep Med. 2012;10:180-90.

14. Kokras N, Dalla C. Preclinical sex differences in depression and antidepressant response: Implications for clinical research. J Neurosci Res. 2017;95:731-6.

15. Kornstein SG, Schatzberg AF, Thase ME, Yonkers KA, McCullough JP, Keitner GI, et al. Gender differences in chronic major and double depression. J Affect Disord. 2000;60:1-11.

16. Mendrek A, Mancini-Marie A. Sex/gender differences in the brain and cognition in schizophrenia. Neurosci Biobehav Rev. 2016;67:57-78. Acomprehensive review of sex/gender differences in the symptoms presented in schizophrenia

17. Ramtekkar UP, Reiersen AM, Todorov AA, Todd RD. Sex and age differences in attention-deficit/hyperactivity disorder symptoms and diagnoses: implications for DSM-V and ICD-11. J Am Acad Child Adolesc Psychiatry. 2010;49:217-28. e211-213

18. Bálint $\mathrm{S}$, Czobor $\mathrm{P}$, Komlósi $\mathrm{S}$, Mészáros Á, Simon V, Bitter I. Attention deficit hyperactivity disorder (ADHD): gender- and age-related differences in neurocognition. Psychol Med. 2008;39:1337-45.

19. Williamson D, Johnston C. Gender differences in adults with attention-deficit/ hyperactivity disorder: a narrative review. Clin Psychol Rev. 2015;40:15-27.

20. Cortese S, Faraone SV, Bernardi S, Wang S, Blanco C. Gender differences in adult attention-deficit/hyperactivity disorder: results from the National Epidemiologic Survey on Alcohol and Related Conditions (NESARC). J Clin Psychiatry. 2016;77: e421-428.

21. Gershon J, Gershon J. A meta-analytic review of gender differences in ADHD. J Atten Disord. 2002;5:143-54. An important meta-analysis of gender differences in the presentation of attention deficit hyperactivity disorder symptoms 
22. Leger $M$, Neill JC. A systematic review comparing sex differences in cognitive function in schizophrenia and in rodent models for schizophrenia, implications for improved therapeutic strategies. Neurosci Biobehav Rev. 2016; 68:979-1000.

23. Torniainen $M$, Suvisaari J, Partonen T, Castaneda AE, Kuha A, Perälä J, et al. Sex differences in cognition among persons with schizophrenia and healthy firstdegree relatives. Psychiatry Res. 2011;188:7-12.

24. Seidman LJ, Goldstein JM, Goodman JM, Koren D, Turner WM, Faraone SV, et al. Sex differences in olfactory identification and Wisconsin card sorting performance in schizophrenia: relationship to attention and verbal ability. Biol Psychiatry. 1997;42:104-15.

25. Zhang B, Han M, Tan S, De Yang F, Tan Y, Jiang S, et al. Gender differences measured by the MATRICS consensus cognitive battery in chronic schizophrenia patients. Sci Rep. 2017;7:11821.

26. Zhang XY, Chen DC, Xiu MH, Yang FD, Haile CN, Kosten TA, et al. Gender differences in never-medicated first-episode schizophrenia and medicated chronic schizophrenia patients. J Clin Psychiatry. 2012;73:1025-33.

27. Goldstein JM, Seidman LJ, Goodman JM, Koren D, Lee H, Weintraub S, et al. Are there sex differences in neuropsychological functions among patients with schizophrenia? Am J Psychiatry. 1998;155:1358-64.

28. Zanelli J, Morgan K, Dazzan P, Morgan C, Russo M, Pilecka I, et al. Gender differences in neuropsychological performance across psychotic disorders-a Multi-Centre Population Based Case-Control Study. PLoS One. 2013;8: e77318.

29. Fond G, Boyer L, Leboyer M, Godin O, Llorca PM, Andrianarisoa M, et al. Influence of Venus and Mars in the cognitive sky of schizophrenia. Results from the first-step national FACE-SZ cohort. Schizophr Res. 2018;195:357-65.

30. Han M, Huang X-F, Chen DC, Xiu MH, Hui L, Liu H, et al. Gender differences in cognitive function of patients with chronic schizophrenia. Prog NeuroPsychopharmacol Biol Psychiatry. 2012;39:358-63.

31. Riboni FV, Belzung C. Stress and psychiatric disorders: from categorical to dimensional approaches. Curr Opin Behav Sci. 2017;14:72-77.

32. Melchior M, Caspi A, Milne BJ, Danese A, Poulton R, Moffitt TE. Work stress precipitates depression and anxiety in young, working women and men. Psychol Med. 2007;37:1119-29.

33. Newman SC, Bland RC. Life events and the 1-year prevalence of major depressive episode, generalized anxiety disorder, and panic disorder in a community sample. Compr Psychiatry. 1994;35:76-82.

34. Hirvikoski $T$, Lindholm $T$, Nordenström A, Nordström A-L, Lajic $S$. High selfperceived stress and many stressors, but normal diurnal cortisol rhythm, in adults with ADHD (attention-deficit/hyperactivity disorder). Horm Behav. 2009:55:418-24.

35. Holtzman CW, Trotman HD, Goulding SM, Ryan AT, MacDonald AN, Shapiro DI, et al. Stress and neurodevelopmental processes in the emergence of psychosis. Neuroscience. 2013;249:172-91.

36. Sara SJ. The locus coeruleus and noradrenergic modulation of cognition. Nat Rev Neurosci. 2009;10:211-23.

37. Swanson LW, Hartman BK. The central adrenergic system. An immunofluorescence study of the location of cell bodies and their efferent connections in the rat utilizing dopamine-beta-hydroxylase as a marker. J Comp Neurol. 1975;163:467-505.

38. Szabadi E. Functional neuroanatomy of the central noradrenergic system. J Psychopharmacol. 2013;27:659-93.

39. Aston-Jones G. The locus coeruleus, A5 and A7 noradrenergic cell groups. In: Paxinos G, editor. The rat nervous system. 3rd ed. Academic Press, 2004. p. 259-87 New York. Agood reference for the anatomy of the locus coeruleus and other metencephalic norepinephrine neuronal systems in the rat.

40. Abercrombie ED, Keller RW, Zigmond MJ. Characterization of hippocampal norepinephrine release as measured by microdialysis perfusion: pharmacological and behavioral studies. Neuroscience. 1988;27:897-904.

41. Morrison JH, Grzanna R, Molliver ME, Coyle JT. The distribution and orientation of noradrenergic fibers in neocortex of the rat: an immunofluorescence study. J Comp Neurol. 1978;181:17-39.

42. Berridge CW, Abercrombie ED. Relationship between locus coeruleus discharge rates and rates of norepinephrine release within neocortex as assessed by in vivo microdialysis. Neuroscience. 1999;93:1263-70.

43. Berridge CW, Foote SL. Effects of locus coeruleus activation on electroencephalographic activity in the neocortex and hippocampus. J Neurosci. 1991;11:3135-45.

44. Berridge CW, Page ME, Valentino RJ, Foote SL. Effects of locus coeruleus inactivation on electroencephalographic activity in neocortex and hippocampus. Neuroscience. 1993;55:381-3.

45. Aston-Jones G, Bloom FE. Activity of norepinephrine-containing locus coeruleus neurons in behaving rats anticipates fluctuations in the sleep-waking cycle. J Neurosci. 1981;1:876-86.
46. Foote SL, Aston-Jones G, Bloom FE. Impulse activity of locus coeruleus neurons in awake rats and monkeys is a function of sensory stimulation and arousal. Proc Natl Acad Sci USA. 1980;77:3033-7.

47. Aston-Jones G, Bloom FE. Norepinephrine-containing locus coeruleus neurons in behaving rats exhibit pronounced responses to non-noxious environmental stimuli. J Neurosci. 1981;1:887-900.

48. Bangasser DA, Curtis A, Reyes BA, Bethea $\Pi$, Parastatidis I, Ischiropoulos $\mathrm{H}$, et al. Sex differences in corticotropin-releasing factor receptor signaling and trafficking: potential role in female vulnerability to stress-related psychopathology. Mol Psychiatry. 2010;15:877. 896-904First demonstration of sex differences in stress receptor signaling and trafficking

49. Bangasser DA, Reyes BA, Piel D, Garachh V, Zhang XY, Plona ZM, et al. Increased vulnerability of the brain norepinephrine system of females to corticotropinreleasing factor overexpression. Mol Psychiatry. 2013;18:166-73.

50. Curtis AL, Bethea T, Valentino RJ. Sexually dimorphic responses of the brain norepinephrine system to stress and corticotropin-releasing factor. Neuropsychopharmacology. 2006;31:544-54. First demonstration of sex differences in locus coeruleus neuronal sensitivity to corticotropin releasing factor

51. Ohm TG, Busch C, Bohl J. Unbiased estimation of neuronal numbers in the human nucleus coeruleus during aging. Neurobiol Aging. 1997;18:393-9.

52. Busch C, Bohl J, Ohm TG. Spatial, temporal and numeric analysis of Alzheimer changes in the nucleus coeruleus. Neurobiol Aging. 1997;18:401-6.

53. Pinos H, Collado P, Rodriguez-Zafra M, Rodriguez C, Segovia S, Guillamon A. The development of sex differences in the locus coeruleus of the rat. Brain Res Bull. 2001;56:73-78.

54. Garcia-Falgueras A, Pinos H, Fernandez R, Collado P, Pasaro E, Segovia S, et al. Sexual dimorphism in hybrids rats. Brain Res. 2006;1123:42-50.

55. Guillamon A, de Blas MR, Segovia S. Effects of sex steroids on the development of the locus coeruleus in the rat. Brain Res. 1988;468:306-10. Identified sex differences in the locus coeruleus size and revealed a contribution of steroid hormones to this sexual differentiation

56. Hormigo S, Gómez-Nieto R, Sancho C, Herrero-Turrión J, Carro J, López DE, et al. Morphological correlates of sex differences in acoustic startle response and prepulse inhibition through projections from locus coeruleus to cochlear root neurons. Brain Struct Funct. 2017;222:3491-508.

57. Mitra SW, Hoskin E, Yudkovitz J, Pear L, Wilkinson HA, Hayashi S, et al. Immunolocalization of estrogen receptor $\beta$ in the mouse brain: comparison with estrogen receptor a. Endocrinology. 2003;144:2055-67.

58. Shughrue PJ, Lane MV, Merchenthaler I. Comparative distribution of estrogen receptor-alpha and -beta mRNA in the rat central nervous system. J Comp Neurol. 1997;388:507-25.

59. Bangasser DA, Wiersielis KR, Khantsis S. Sex differences in the locus coeruleusnorepinephrine system and its regulation by stress. Brain Res. 2016;1641:177-88.

60. Pau KY, Hess DL, Kohama S, Bao J, Pau CY, Spies HG. Oestrogen upregulates noradrenaline release in the mediobasal hypothalamus and tyrosine hydroxylase gene expression in the brainstem of ovariectomized rhesus macaques. $J$ Neuroendocrinol. 2000;12:899-909.

61. Serova L, Rivkin M, Nakashima A, Sabban EL. Estradiol stimulates gene expression of norepinephrine biosynthetic enzymes in rat locus coeruleus. Neuroendocrinology. 2002;75:193-200.

62. Maharjan S, Serova L, Sabban EL. Transcriptional regulation of tyrosine hydroxylase by estrogen: opposite effects with estrogen receptors alpha and beta and interactions with cyclic AMP. J Neurochem. 2005;93:1502-14.

63. Serova LI, Nostramo R, Veerasirikul M, Cappell DB, Sabban EL. Varied mechanisms of oestradiol-mediated regulation of dopamine beta-hydroxylase transcription. J Neuroendocrinol. 2011;23:168-76.

64. Parvez S, Ismahan G, Raza-Bukhari A, Youdim MB. Activity of catechol-omethyltransferase in brain regions and adrenal gland during the oestrus cycle. J Neural Transm. 1978;42:305-12.

65. Jiang $\mathrm{H}$, Xie T, Ramsden DB, Ho SL. Human catechol-O-methyltransferase downregulation by estradiol. Neuropharmacology. 2003;45:1011-8.

66. Chen J, Lipska BK, Halim N, Ma QD, Matsumoto M, Melhem S, et al. Functional analysis of genetic variation in catechol-O-methyltransferase (COMT): effects on mRNA, protein, and enzyme activity in postmortem human brain. Am J Hum Genet. 2004;75:807-21.

67. Vathy I, Etgen AM. Ovarian steroids and hypothalamic norepinephrine release: studies using in vivo brain microdialysis. Life Sci. 1988;43:1493-9.

68. Karkanias GB, Li CS, Etgen AM. Estradiol reduction of alpha 2-adrenoceptor binding in female rat cortex is correlated with decreases in alpha 2A/D-adrenoceptor messenger RNA. Neuroscience. 1997;81:593-7.

69. Bücheler MM, Hadamek K, Hein L. Two a2-adrenergic receptor subtypes, a2A and $\mathrm{a}_{2} \mathrm{C}$, inhibit transmitter release in the brain of gene-targeted mice. Neuroscience. 2002;109:819-26. 
70. Meitzen J, Perry AN, Westenbroek C, Hedges VL, Becker JB, Mermelstein PG. Enhanced striatal beta1-adrenergic receptor expression following hormone loss in adulthood is programmed by both early sexual differentiation and puberty: a study of humans and rats. Endocrinology. 2013;154:1820-31.

71. Biegon A, Reches A, Snyder L, McEwen BS. Serotonergic and noradrenergic receptors in the rat brain: modulation by chronic exposure to ovarian hormones. Life Sci. 1983;32:2015-21.

72. Shansky RM, Bender G, Arnsten AF. Estrogen prevents norepinephrine alpha-2a receptor reversal of stress-induced working memory impairment. Stress. 2009;12:457-63.

73. Liaw J-J, He J-R, Hartman RD, Barraclough CA. Changes in tyrosine hydroxylase mRNA levels in medullary $A 1$ and $A 2$ neurons and locus coeruleus following castration and estrogen replacement in rats. Mol Brain Res. 1992;13:231-8.

74. Hamson DK, Jones BA, Watson NV. Distribution of androgen receptor immunoreactivity in the brainstem of male rats. Neuroscience. 2004;127:797-803.

75. Dygalo NN, Kalinina TS, Sournina NY, Shishkina GT. Effects of testosterone on alpha2A-adrenergic receptor expression in the rat brain. Psychoneuroendocrinology. 2002;27:585-92.

76. Bangasser DA, Zhang X, Garachh V, Hanhauser E, Valentino RJ. Sexual dimorphism in locus coeruleus dendritic morphology: a structural basis for sex differences in emotional arousal. Physiol Behav. 2011;103:342-51.

77. Aston-Jones G, Ennis M, Pieribone VA, Nickell WT, Shipley MT. The brain nucleus locus coeruleus: restricted afferent control of a broad efferent network. Science. 1986;234:734-7.

78. Valentino RJ, Chen S, Zhu Y, Aston-Jones G. Evidence for divergent projections of corticotropin-releasing hormone neurons of Barrington's nucleus to the locus coeruleus and spinal cord. Brain Res. 1996;732:1-15.

79. Shipley MT, Fu L, Ennis M, Liu W, Aston-Jones G. Dendrites of locus coeruleus neurons extend preferentially into two pericoerulear zones. J Comp Neurol. 1996;365:56-68.

80. Valentino RJ, Page ME, Van Bockstaele E, Aston-Jones G. Corticotropin-releasing factor innervation of the locus coeruleus region: distribution of fibers and sources of input. Neuroscience. 1992;48:689-705.

81. Van Bockstaele EJ, Bajic D, Proudfit H, Valentino RJ. Topographic architecture of stress-related pathways targeting the noradrenergic locus coeruleus. Physiol Behav. 2001;73:273-83.

82. Reyes BA, Valentino RJ, Xu G, Van Bockstaele EJ. Hypothalamic projections to locus coeruleus neurons in rat brain. Eur J Neurosci. 2005;22:93-106.

83. Van Bockstaele EJ, Colago EE, Valentino RJ. Amygdaloid corticotropin-releasing factor targets locus coeruleus dendrites: substrate for the co-ordination of emotional and cognitive limbs of the stress response. J Neuroendocrinol. 1998;10:743-57.

84. Van Bockstaele EJ, Peoples J, Valentino RJ. A.E. Bennett Research Award. Anatomic basis for differential regulation of the rostrolateral peri-locus coeruleus region by limbic afferents. Biol Psychiatry. 1999;46:1352-63.

85. Van Bockstaele EJ, Peoples J, Telegan P. Efferent projections of the nucleus of the solitary tract to peri-locus coeruleus dendrites in rat brain: evidence for a monosynaptic pathway. J Comp Neurol. 1999;412:410-28.

86. Labus JS, Naliboff BN, Fallon J, Berman SM, Suyenobu B, Bueller JA, et al. Sex differences in brain activity during aversive visceral stimulation and its expectation in patients with chronic abdominal pain: a network analysis. Neuroimage. 2008;41:1032-43.

87. Curtis AL, Lechner SM, Pavcovich LA, Valentino RJ. Activation of the locus coeruleus noradrenergic system by intracoerulear microinfusion of corticotropin-releasing factor: effects on discharge rate, cortical norepinephrine levels and cortical electroencephalographic activity. J Pharmacol Exp Ther. 1997;281:163-72.

88. Valentino RJ, Foote SL, Page ME. The locus coeruleus as a site for integrating corticotropin-releasing factor and noradrenergic mediation of stress responses. Ann N Y Acad Sci. 1993;697:173-88.

89. Valentino RJ, Van Bockstaele E. Functional interactions between stress neuromediator and the locus coeruleur-noradrenaline system. In: Steckler TKN, (ed). Handbook of stress and the brain. The Netherlands: Elsevier; 2005. p. 465-86.

90. Valentino RJ, Wehby RG. Corticotropin-releasing factor: evidence for a neurotransmitter role in the locus ceruleus during hemodynamic stress. Neuroendocrinology. 1988;48:674-7

91. Valentino RJ, Foote SL. Corticotropin-releasing factor disrupts sensory responses of brain noradrenergic neurons. Neuroendocrinology. 1987;45:28-36.

92. Valentino RJ, Foote SL. Corticotropin-releasing hormone increases tonic but not sensory-evoked activity of noradrenergic locus coeruleus neurons in unanesthetized rats. J Neurosci. 1988;8:1016-25.

93. Aston-Jones G, Cohen JD. An integrative theory of locus coeruleusnorepinephrine function: adaptive gain and optimal performance. Annu Rev Neurosci. 2005;28:403-50.
94. Snyder K, Wang WW, Han R, McFadden K, Valentino RJ. Corticotropin-releasing factor in the norepinephrine nucleus, locus coeruleus, facilitates behavioral flexibility. Neuropsychopharmacology. 2012;37:520-30.

95. McCarthy MM, Arnold AP, Ball GF, Blaustein JD, De Vries GJ. Sex differences in the brain: the not so inconvenient truth. J Neurosci. 2012;32:2241-7. Excellent primer on how to classify and study sex differences in the brain, a must read for those studying sex differences

96. Schulz C, Lehnert $\mathrm{H}$. Activation of noradrenergic neurons in the locus coeruleus by corticotropin-releasing factor, a microdialysis study. Neuroendocrinology. 1996;63:454-8.

97. Jedema HP, Grace AA. Corticotropin-releasing hormone directly activates noradrenergic neurons of the locus ceruleus recorded in vitro. J Neurosci. 2004;24:9703-13.

98. Battaglia G, Webster EL, De Souza EB. Characterization of corticotropin-releasing factor receptor-mediated adenylate cyclase activity in the rat central nervous system. Synapse. 1987;1:572-81.

99. Chen FM, Bilezikjian LM, Perrin MH, Rivier J, Vale W. Corticotropin releasing factor receptor-mediated stimulation of adenylate cyclase activity in the rat brain. Brain Res. 1986;381:49-57.

100. Grammatopoulos DK, Randeva HS, Levine MA, Kanellopoulou KA, Hillhouse EW. Rat cerebral cortex corticotropin-releasing hormone receptors: evidence for receptor coupling to multiple G-proteins. J Neurochem. 2001;76:509-19. Demonstrated promiscuous coupling of the corticotropin-releasing hormone receptors.

101. Nemeroff CB, Bissette G, Akil H, Fink M. Neuropeptide concentrations in the cerebrospinal fluid of depressed patients treated with electroconvulsive therapy. Corticotrophin-releasing factor, beta-endorphin and somatostatin. $\mathrm{Br} \mathrm{J}$ Psychiatry. 1991;158:59-63.

102. Stenzel-Poore MP, Cameron VA, Vaughan J, Sawchenko PE, Vale W. Development of Cushing's syndrome in corticotropin-releasing factor transgenic mice. Endocrinology. 1992;130:3378-86.

103. Bremner JD, Licinio J, Darnell A, Krystal JH, Owens MJ, Southwick SM, et al. Elevated CSF corticotropin-releasing factor concentrations in posttraumatic stress disorder. Am J Psychiatry. 1997;154:624-9.

104. Bangasser DA, Dong $H$, Carroll J, Plona $Z$, Ding $H$, Rodriguez $L$, et al. Corticotropin-releasing factor overexpression gives rise to sex differences in Alzheimer's disease-related signaling. Mol Psychiatry. 2017;8:1126-33.

105. Van Pett K, Viau V, Bittencourt JC, Chan RK, Li HY, Arias C, et al. Distribution of mRNAs encoding CRF receptors in brain and pituitary of rat and mouse. J Comp Neurol. 2000;428:191-212.

106. Lefkowitz RJ, Shenoy SK. Transduction of receptor signals by beta-arrestins. Science. 2005;308:512-7.

107. Shukla AK, Xiao K, Lefkowitz RJ. Emerging paradigms of beta-arrestindependent seven transmembrane receptor signaling. Trends Biochem Sci. 2011;36:457-69.

108. Valentino RJ, Bangasser D, Van Bockstaele EJ. Sex-biased stress signaling: the corticotropin-releasing factor receptor as a model. Mol Pharmacol. 2013;83:737-45.

109. Valentino RJ, Van Bockstaele E, Bangasser D. Sex-specific cell signaling: the corticotropin-releasing factor receptor model. Trends Pharmacol Sci. 2013;34:437-44. Detailed description of sex differences in receptor signaling and the implications for sex tailored pharmacotherapy

110. Hauger RL, Risbrough V, Oakley RH, Olivares-Reyes JA, Dautzenberg FM. Role of CRF receptor signaling in stress vulnerability, anxiety, and depression. Ann N Y Acad Sci. 2009;1179:120-43.

111. Hillhouse EW, Randeva H, Ladds G, Grammatopoulos D. Corticotropin-releasing hormone receptors. Biochem Soc Trans. 2002;30:428-32.

112. Teli T, Markovic D, Levine MA, Hillhouse EW, Grammatopoulos DK. Regulation of corticotropin-releasing hormone receptor type 1alpha signaling: structural determinants for $\mathrm{G}$ protein-coupled receptor kinase-mediated phosphorylation and agonist-mediated desensitization. Mol Endocrinol. 2005;19:474-90.

113. Oakley RH, Olivares-Reyes JA, Hudson CC, Flores-Vega F, Dautzenberg FM, Hauger RL. Carboxyl-terminal and intracellular loop sites for CRF1 receptor phosphorylation and beta-arrestin- 2 recruitment: a mechanism regulating stress and anxiety responses. Am J Physiol Regul Integr Comp Physiol. 2007;293:R209-222.

114. Holmes KD, Babwah AV, Dale LB, Poulter MO, Ferguson SS. Differential regulation of corticotropin releasing factor 1alpha receptor endocytosis and trafficking by beta-arrestins and Rab GTPases. J Neurochem. 2006;96:934-49.

115. Reyes BA, Valentino RJ, Van Bockstaele EJ. Stress-induced intracellular trafficking of corticotropin-releasing factor receptors in rat locus coeruleus neurons. Endocrinology. 2008;149:122-30.

116. Guajardo HM, Snyder K, Ho A, Valentino RJ. Sex differences in $\mu$-opioid receptor regulation of the rat locus coeruleus and their cognitive consequences. Neuropsychopharmacology. 2017;42:1295-304. 
117. Saper CB, Fuller PM. Wake-sleep circuitry: an overview. Curr Opin Neurobiol. 2017:44:186-92. A good review of the systems that regulate sleep and wakefulness

118. Cho JR, Treweek JB, Robinson JE, Xiao C, Bremner LR, Greenbaum A, et al. Dorsal raphe dopamine neurons modulate arousal and promote wakefulness by salient stimuli. Neuron. 2017:94:1205-19. e1208

119. Seltzer AM, Donoso AO. Effects of ovariectomy and ovarian steroids on binding of 3H-mepyramine, an $\mathrm{H} 1$-histamine antagonist, in rat hypothalamus. Brain Res Bull. 1989;23:183-6.

120. Ghi $P$, Ferretti $C$, Lupi ML, Blengio $M$, Portaleone P. Sexual dimorphism in $[3 \mathrm{H}]$ histamine binding sites of rat cerebral cortex. Pharmacol Res. 1991;23:187-93.

121. Dalla C, Antoniou K, Kokras N, Drossopoulou G, Papathanasiou G, Bekris S, et al. Sex differences in the effects of two stress paradigms on dopaminergic neurotransmission. Physiol Behav. 2008;93:595-605.

122. Georgiou P, Zanos P, Bhat S, Tracy JK, Merchenthaler IJ, McCarthy MM, et al. Dopamine and Stress System Modulation of Sex Differences in Decision Making. Neuropsychopharmacology. 2017:43:313.

123. Howerton AR, Roland AV, Fluharty JM, Marshall A, Chen A, Daniels D, et al. Sex differences in corticotropin-releasing factor receptor-1 action within the dorsal raphe nucleus in stress responsivity. Biol Psychiatry. 2014;75:873-83.

124. Rincón-Cortés M, Grace AA. Sex-dependent effects of stress on immobility behavior and VTA dopamine neuron activity: modulation by ketamine. Int J Neuropsychopharmacol. 2017;20:823-32.

125. Grafe LA, Cornfeld A, Luz S, Valentino R, Bhatnagar S. Orexins mediate sex differences in the stress response and in cognitive flexibility. Biol Psychiatry. 2017;81:683-92. Demonstrated sex differences in the orexin system and its regulation by stress, and highlighted the implications of these sex differences for cognitive flexibility

126. Jöhren O, Neidert SJ, Kummer M, Dominiak P. Sexually dimorphic expression of prepro-orexin mRNA in the rat hypothalamus. Peptides. 2002;23:1177-80.

127. Stange JP, Connolly SL, Burke TA, Hamilton JL, Hamlat EJ, Abramson LY, et al. Inflexible cognition predicts first onset of major depressive episodes in adolescence. Depress Anxiety. 2016;33:1005-12.

128. White EK, Warren CS, Cao L, Crosby RD, Engel SG, Wonderlich SA, et al. Media exposure and associated stress contribute to eating pathology in women with anorexia nervosa: daily and momentary associations. Int J Eat Disord. 2016;49:617-21.

129. Lang K, Treasure J, Tchanturia K. Is inefficient cognitive processing in anorexia nervosa a familial trait? A neuropsychological pilot study of mothers of offspring with a diagnosis of anorexia nervosa. World J Biol Psychiatry. 2016;17: 258-65.

130. Ballinger Elizabeth C, Ananth M, Talmage David A, Role Lorna W. Basal forebrain cholinergic circuits and signaling in cognition and cognitive decline. Neuron. 2016;91:1199-218.

131. Zaborszky L, van den Pol A, Gyengesi E. The basal forebrain cholinergic projection system in mice. Mouse Nerv Syst 2012;1:684-714. Describes cholinergic nuclei in the basal forebrain and their roles in cognition and arousal.

132. Chang Q, Gold PE. Impaired and spared cholinergic functions in the hippocampus after lesions of the medial septum/vertical limb of the diagonal band with 192 lgG-saporin. Hippocampus. 2004;14:170-9.

133. Amaral DG, Kurz J. An analysis of the origins of the cholinergic and noncholinergic septal projections to the hippocampal formation of the rat. J Comp Neurol. 1985;240:37-59.

134. Easton A, Fitchett AE, Eacott MJ, Baxter MG. Medial septal cholinergic neurons are necessary for context-place memory but not episodic-like memory. Hippocampus. 2011;21:1021-7.

135. Turchi J, Sarter M. Cortical acetylcholine and processing capacity: effects of cortical cholinergic deafferentation on crossmodal divided attention in rats. Cogn Brain Res. 1997;6:147-58.

136. Guillem K, Bloem B, Poorthuis RB, Loos M, Smit AB, Maskos U, et al. Nicotinic acetylcholine receptor $\beta 2$ subunits in the medial prefrontal cortex control attention. Science. 2011;333:888-91.

137. Herrero JL, Roberts M, Delicato L, Gieselmann MA, Dayan P, Thiele A. Acetylcholine contributes through muscarinic receptors to attentional modulation in V1. Nature. 2008;454:1110.

138. McGaughy J, Kaiser T, Sarter M. Behavioral vigilance following infusions of 192 lgG-saporin into the basal forebrain: selectivity of the behavioral impairment and relation to cortical AChE-positive fiber density. Behav Neurosci. 1996;110:247-65. Demonstrated the role of cholinergic neurons in the nucleus basalis of Meynert in performance on a sustained attention task

139. McGaughy J, Sarter M. Effects of ovariectomy, 192 lgG-saporin-induced cortical cholinergic deafferentation, and administration of estradiol on sustained attention performance in rats. Behav Neurosci. 1999;113:1216-32.

140. Sarter M, Givens B, Bruno JP. The cognitive neuroscience of sustained attention: where top-down meets bottom-up. Brain Res Brain Res Rev. 2001;35:146-60. A detailed review of the brain circuitry necessary for sustained attention with a focus on the basal forebrain cholinergic system

141. Parikh V, Kozak R, Martinez V, Sarter M. Prefrontal acetylcholine release controls cue detection on multiple timescales. Neuron. 2007;56:141-54.

142. Parikh V, Sarter M. Cholinergic mediation of attention: contributions of phasic and tonic increases in prefrontal cholinergic activity. Ann $\mathrm{N}$ Y Acad Sci. 2008;1129:225-35.

143. Gritton HJ, Howe WM, Mallory CS, Hetrick VL, Berke JD, Sarter M. Cortical cholinergic signaling controls the detection of cues. Proc Natl Acad Sci. 2016;113: E1089-E1097.

144. Rogers SL, Friedhoff LT. The efficacy and safety of donepezil in patients with Alzheimer's disease: results of a US Multicentre, randomized, double-blind, placebo-controlled trial. Dement Geriatr Cogn Disord. 1996;7:293-303.

145. Winblad B, Wimo A, Engedal K, Soininen H, Verhey F, Waldemar G, et al. 3-Year study of Donepezil therapy in Alzheimer's disease: effects of early and continuous therapy. Dement Geriatr Cogn Disord. 2006;21:353-63.

146. Francis PT, Palmer AM, Snape M, Wilcock GK. The cholinergic hypothesis of Alzheimer's disease: a review of progress. J Neurol, Neurosurg . 1999;66:137.

147. Potter AS, Dunbar G, Mazzulla E, Hosford D, Newhouse PA. AZD3480, a novel nicotinic receptor agonist, for the treatment of attention-deficit/hyperactivity disorder in adults. Biol Psychiatry. 2014;75:207-14.

148. Keefe RS, Meltzer HA, Dgetluck N, Gawryl M, Koenig G, Moebius HJ, et al. Randomized, double-blind, placebo-controlled study of encenicline, an a7 nicotinic acetylcholine receptor agonist, as a treatment for cognitive impairment in schizophrenia. Neuropsychopharmacology. 2015;40:3053.

149. Takase K, Kimura F, Yagami T, Mitsushima D. Sex-specific 24-h acetylcholine release profile in the medial prefrontal cortex: simultaneous measurement of spontaneous locomotor activity in behaving rats. Neuroscience. 2009;159:7-15. Reveals increased activity of the basal forebrain cholinergic attention system in females compared to males

150. Takase K, Mitsushima D, Funabashi T, Kimura F. Sex difference in the 24-h acetylcholine release profile in the premotor/supplementary motor area of behaving rats. Brain Res. 2007;1154:105-15.

151. Gibbs RB. Expression of estrogen receptor-like immunoreactivity by different subgroups of basal forebrain cholinergic neurons in gonadectomized male and female rats. Brain Res. 1996;720:61-8.

152. Kritzer MF, Kohama SG. Ovarian hormones differentially influence immunoreactivity for dopamine $\beta$-hydroxylase, choline acetyltransferase, and serotonin in the dorsolateral prefrontal cortex of adult rhesus monkeys. J Comp Neurol. 1999;409:438-51.

153. Luine VN. Estradiol increases choline acetyltransferase activity in specific basal forebrain nuclei and projection areas of female rats. Exp Neurol. 1985;89:484-90. Demonstrated that estradiol increases choline acetyltransferase activity in certain cholinergic nuclei of the basal forebrain

154. Singh M, Meyer EM, Millard WJ, Simpkins JW. Ovarian steroid deprivation results in a reversible learning impairment and compromised cholinergic function in female Sprague-Dawley rats. Brain Res. 1994;644:305-12.

155. Gibbs RB. Effects of estrogen on basal forebrain cholinergic neurons vary as a function of dose and duration of treatment. Brain Res. 1997;757:10-16.

156. Miettinen RA, Kalesnykas G, Koivisto EH. Estimation of the total number of cholinergic neurons containing estrogen receptor-alpha in the rat basal forebrain. J Histochem Cytochem. 2002;50:891-902.

157. Hammond R, Nelson D, Gibbs RB. GPR30 co-localizes with cholinergic neurons in the basal forebrain and enhances potassium-stimulated acetylcholine release in the hippocampus. Psychoneuroendocrinology. 2011;36:182-92.

158. McMillan $P$, Singer $C$, Dorsa D. The effects of ovariectomy and estrogen replacement on trkA and choline acetyltransferase mRNA expression in the basal forebrain of the adult female Sprague-Dawley rat. J Neurosci. 1996;16:1860-5.

159. Milne MR, Haug CA, Ábrahám IM, Kwakowsky A. Estradiol modulation of neurotrophin receptor expression in female mouse basal forebrain cholinergic neurons in vivo. Endocrinology. 2015;156:613-26.

160. Nakamura N, Fujita $H$, Kawata M. Effects of gonadectomy on immunoreactivity for choline acetyltransferase in the cortex, hippocampus, and basal forebrain of adult male rats. Neuroscience. 2002;109:473-85.

161. Cosgrove KP, Esterlis I, McKee SA, et al. Sex differences in availability of $\beta 2^{*}-$ nicotinic acetylcholine receptors in recently abstinent tobacco smokers. Arch Gen Psychiatry. 2012;69:418-27.

162. Perry DC, Xiao Y, Nguyen HN, Musachio JL, Dávila-García MI, Kellar KJ. Measuring nicotinic receptors with characteristics of $\alpha 4 \beta 2, \alpha 3 \beta 2$ and $\alpha 3 \beta 4$ subtypes in rat tissues by autoradiography. J Neurochem. 2002;82:468-81.

163. Paradiso K, Zhang J, Steinbach JH. The $C$ terminus of the human nicotinic $a 4 \beta 2$ receptor forms a binding site required for potentiation by an estrogenic steroid. J Neurosci. 2001;21:6561.

164. Curtis L, Buisson B, Bertrand S, Bertrand D. Potentiation of human a $4 \beta 2$ neuronal nicotinic acetylcholine receptor by estradiol. Mol Pharmacol. 2002;61:127. 
165. Tinkler GP, Voytko ML. Estrogen modulates cognitive and cholinergic processes in surgically menopausal monkeys. Prog Neuro-Psychopharmacol Biol Psychiatry. 2005;29:423-31.

166. Court J, Martin-Ruiz C, Piggott M, Spurden D, Griffiths M, Perry E. Nicotinic receptor abnormalities in Alzheimer's disease. Biol Psychiatry. 2001;49: 175-84.

167. Maki PM. A systematic review of clinical trials of hormone therapy on cognitive function: effects of age at initiation and progestin use. Ann N Y Acad Sci. 2005;1052:182-97.

168. Witt ED, Mantione CR, Hanin I. Sex differences in muscarinic receptor binding after chronic ethanol administration in the rat. Psychopharmacology (Berlin). 1986;90:537-42.

169. Yoshida T, Kuwabara Y, Sasaki M, Fukumura T, Ichimiya A, Takita M, et al. Sexrelated differences in the muscarinic acetylcholinergic receptor in the healthy human brain-a positron emission tomography study. Ann Nucl Med. 2000;14:97-101.

170. Norbury R, Travis MJ, Erlandsson K, Waddington W, Ell PJ, Murphy DGM. Estrogen therapy and brain muscarinic receptor density in healthy females: a SPET study. Horm Behav. 2007;51:249-57.

171. Bangasser DA, Wicks B, Waxler DE, Eck SR. Touchscreen sustained attention task (SAT) for rats. J Vis Exp. 2017;e56219.

172. Cole RD, Kawasumi Y, Parikh V, Bangasser DA. Corticotropin releasing factor impairs sustained attention in male and female rats. Behav Brain Res. 2016;296:30-4. Demonstrated disruptions in attention following corticotropin releasing factor administration and the regulation of this effect by estrous cycle stage

173. Salvatore M, Wiersielis KR, Luz S, Waxler DE, Bhatnagar S, Bangasser DA. Sex differences in circuits activated by corticotropin releasing factor in rats. Horm Behav. 2018;97:145-53

174. Wiersielis KR, Wicks B, Simko H, Cohen SR, Khantsis S, Baksh N, et al. Sex differences in corticotropin releasing factor-evoked behavior and activated networks. Psychoneuroendocrinology. 2016;73:204-16.

175. Akama KT, Thompson LI, Milner TA, McEwen BS. Post-synaptic density-95 (PSD95) binding capacity of G-protein-coupled receptor 30 (GPR30), an estrogen receptor that can be identified in hippocampal dendritic spines. J Biol Chem. 2013;288:6438-50.

176. Bangasser D, Telenson A, Wicks B, Bergmann J, Shore M, Newcamp N, Chronic stress regulation of sustained attention and cholinergic dendritic morphology in rats. Neuropsychopharmaocology. 2017;43:S653-S700.

177. Albeck DS, McKittrick CR, Blanchard DC, Blanchard RJ, Nikulina J, McEwen BS, et al. Chronic social stress alters levels of corticotropin-releasing factor and arginine vasopressin mRNA in rat brain. J Neurosci. 1997;17:4895-903.

178. Pérez MÁ, Pérez-Valenzuela C, Rojas-Thomas F, Ahumada J, Fuenzalida $M$, Dagnino-Subiabre $A$. Repeated restraint stress impairs auditory attention and GABAergic synaptic efficacy in the rat auditory cortex. Neuroscience. 2013;246:94-107.

179. Wilson CA, Schade R, Terry AV Jr. Variable prenatal stress results in impairments of sustained attention and inhibitory response control in a 5-choice serial reaction time task in rats. Neuroscience. 2012;218:126-37.

180. Luine V, Villegas M, Martinez C, McEwen BS. Repeated stress causes reversible impairments of spatial memory performance. Brain Res. 1994;639:167-70.

181. Mizoguchi K, Yuzurihara M, Ishige A, Sasaki H, Chui D-H, Tabira T. Chronic stress induces impairment of spatial working memory because of prefrontal dopaminergic dysfunction. J Neurosci. 2000;20:1568

182. Wei J, Yuen EY, Liu W, Li X, Zhong P, Karatsoreos IN, et al. Estrogen protects against the detrimental effects of repeated stress on glutamatergic transmission and cognition. Mol Psychiatry. 2014;19:588-98.

183. Beck KD, Luine VN. Sex differences in behavioral and neurochemical profiles after chronic stress: role of housing conditions. Physiol Behav. 2002;75: 661-73.

184. Bodnoff SR, Humphreys AG, Lehman JC, Diamond DM, Rose GM, Meaney MJ. Enduring effects of chronic corticosterone treatment on spatial learning, synaptic plasticity, and hippocampal neuropathology in young and mid-aged rats. J Neurosci. 1995;15:61-69.

185. Bowman RE, Micik R, Gautreaux C, Fernandez L, Luine VN. Sex-dependent changes in anxiety, memory, and monoamines following one week of stress. Physiol Behav. 2009;97:21-29.
186. Kitraki E, Kremmyda O, Youlatos D, Alexis MN, Kittas C. Gender-dependent alterations in corticosteroid receptor status and spatial performance following 21 days of restraint stress. Neuroscience. 2004;125:47-55.

187. Bowman RE, Zrull MC, Luine VN. Chronic restraint stress enhances radial arm maze performance in female rats. Brain Res. 2001;904:279-89.

188. Conrad CD, Grote KA, Hobbs RJ, Ferayorni A. Sex differences in spatial and nonspatial Y-maze performance after chronic stress. Neurobiol Learn Mem. 2003;79:32-40.

189. McEwen BS, Stress, sex, and neural adaptation to a changing environment: mechanisms of neuronal remodeling. Ann N Y Acad Sci. 2010;1204:E38-59.

190. Galea LA, McEwen BS, Tanapat P, Deak T, Spencer RL, Dhabhar FS. Sex differences in dendritic atrophy of CA3 pyramidal neurons in response to chronic restraint stress. Neuroscience. 1997;81:689-97.

191. Mehta N, Rodrigues C, Lamba M, Wu W, Bronskill Susan E, Herrmann N, et al. Systematic review of sex-specific reporting of data: cholinesterase inhibitor example. J Am Geriatr Soc. 2017;65:2213-9.

192. Phillips SP, Hamberg K. Doubly blind: a systematic review of gender in randomised controlled trials. Glob Health Action. 2016;9:29597 https://doi.org/ 10.3402/gha.v3409.29597.

193. Canevelli M, Quarata F, Remiddi F, Lucchini F, Lacorte E, Vanacore N, et al. Sex and gender differences in the treatment of Alzheimer's disease: a systematic review of randomized controlled trials. Pharmacol Res. 2017;115:218-23.

194. Macleod MR, Michie S, Roberts I, Dirnagl U, Chalmers I, loannidis JPA, et al. Biomedical research: increasing value, reducing waste. Lancet. 2014:383:101-4.

195. Will TR, Proaño SB, Thomas AM, Kunz LM, Thompson KC, Ginnari LA, et al. Problems and progress regarding sex bias and omission in neuroscience research. eneuro 2017:4:1-10. Identifies sex biases and omissions in neuroscience publications.

196. Beery AK, Zucker I. Sex bias in neuroscience and biomedical research. Neurosci Biobehav Rev. 2011;35:565-72.

197. Clayton JA, Collins FS. Policy: NIH to balance sex in cell and animal studies. Nature. 2014;509:282-3.

198. Rademaker M. Do women have more adverse drug reactions? Am J Clin Dermatol. 2001;2:349-51.

199. Franconi F, Campesi I, Occhioni S, Antonini P, Murphy MF. Sex and gender in adverse drug events, addiction, and placebo. In: Regitz-Zagrosek V, (ed). Sex and gender differences in pharmacology. Berlin, Heidelberg: Springer; 2012. p. 107-26.

200. Khokan CS, Reza A, Don M, Brendan B, Kayla DC, Jennifer D, et al. Adverse drug events in adult patients leading to emergency department visits. Ann Pharmacother. 2010;44:641-9.

201. O'Brien D, Skelton $\mathrm{KH}$, Owens MJ, Nemeroff CB. Are CRF receptor antagonists potential antidepressants? Hum Psychopharmacol. 2001;16:81-87.

202. Holsboer $F$. The rationale for corticotropin-releasing hormone receptor (CRH-R) antagonists to treat depression and anxiety. J Psychiatr Res. 1999;33:181-214.

203. Spierling SR, Zorrilla EP. Don't stress about CRF: assessing the translational failures of CRF1antagonists. Psychopharmacology (Berlin). 2017;234:1467-81.

204. Dunlop BW, Binder EB, losifescu D, Mathew SJ, Neylan TC, Pape JC, et al. Corticotropin-releasing factor receptor 1 antagonism is ineffective for women with posttraumatic stress disorder. Biol Psychiatry. 2017;82:866-74.

205. Valentino RJ, Reyes B, Van Bockstaele E, Bangasser D. Molecular and cellular sex differences at the intersection of stress and arousal. Neuropharmacology. 2012;62:13-20.

206. Smith JS, Lefkowitz RJ, Rajagopal S. Biased signalling: from simple switches to allosteric microprocessors. Nat Rev Drug Discov. 2018;17:243-60.

207. Violin JD, Lefkowitz RJ. Beta-arrestin-biased ligands at seven-transmembrane receptors. Trends Pharmacol Sci. 2007;28:416-22.

208. Whalen EJ, Rajagopal S, Lefkowitz RJ. Therapeutic potential of beta-arrestin- and G protein-biased agonists. Trends Mol Med. 2011;17:126-39.

209. Seedat S, Scott K, Angermeyer MC, et al. Cross-national associations between gender and mental disorders in the world health organization world mental health surveys. Arch Gen Psychiatry. 2009;66:785-95.

210. Cover KK, Maeng LY, Lebrón-Milad K, Milad MR. Mechanisms of estradiol in fear circuitry: implications for sex differences in psychopathology. Transl Psychiatry. 2014;4:e422.

211. Ansonoff MA, Etgen AM. Estrogen increases $G$ protein coupled receptor kinase 2 in the cortex of female rats. Brain Res. 2001;898:186-9. 